\title{
The effect of Curcurma longa (Turmeric) rhizomes extracts on pathogenic bacteria In comparison with standard antibiotics
}

\author{
تأثير مستخلص السيقان الجذرية للكركم Curcuma longa (Turmeric) على بمفئية \\ البكتريا المرضية بالمقارنة بمضادات الحياة الاساسية
}

Saeed Sahib Allawi , Jassim Mohammad Auda, Hiba Qasim Hameed * Tagreed Ibraheem Ali

Food science and biotech Dept/ College of Agricultural/ Baghdad University * Biology Dept. / college of education / Baghdad University

$$
\begin{aligned}
& \text { سعيد صاحب علاوي ، جاسم محمد عودة ، هبة قاسم حميد* ، تغريد ابراهيم علي }
\end{aligned}
$$

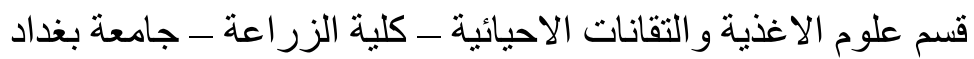

$$
\begin{aligned}
& \text { *قسم علوم الحياة - كلية التربية - جامعة بغداد }
\end{aligned}
$$

\begin{abstract}
:
Four extracts of Curcuma longa rhizomes ( commonly known as turmeric widely used as spice and coloring agent and known for its medical properties) were evaluated for their anti- bacterial action against pathogenic bacteria of gram-negative (Escherichia coli, Salmonella typhimurium ) and gram- positive (Staphylococcus aureus, Bacillus cereus) comparing with antibiotics (gentamycin, ampicillin and erythromycin). Essential oil which was extracted from turmeric found to be most active against pathogenic bacteria in comparison with other extracts (water, chloroform and methanol extract). Using 40 microgram/disc of essential oil of turmeric as a minimum inhibitory concentration posses significant activity on pathogenic gram-negative and gram- positive bacteria.
\end{abstract}

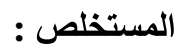

اخذت اربع مستخلصـات للسيقان الجذريـة للكركم Curcuma longa الثـائع تسميته بالـ (Turmeric) والذئي

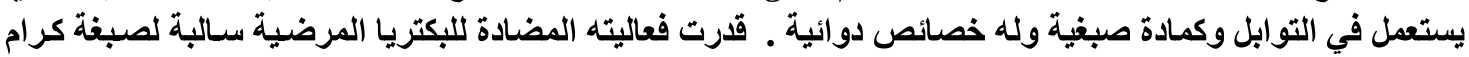

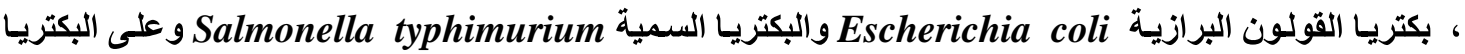

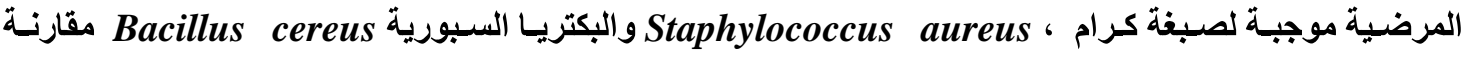

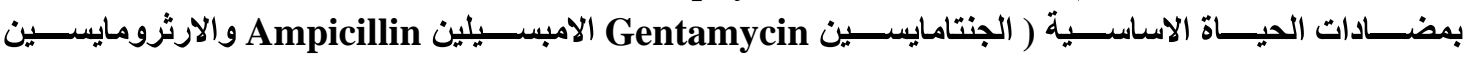
(Erthromycin

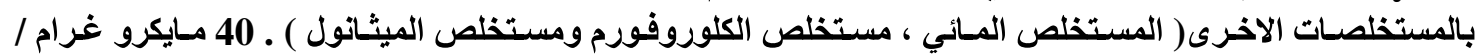

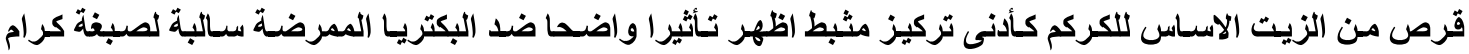

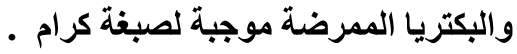




\section{Introduction:}

Curcuma longa which belongs to Zingiberaceae family, commonely known as turmeric is widely used as a spice and coloring agent in food and known for its medicinal properties [1, $2,3,4,5]$.

Turmeric is a perennial herb, cultivated extensively in Asia, India, China and other countries with a tropical climate. The rhizome is the portion of the plant used medicinally, it is usually boiled cleaned and dried yielding a yellow powder, dried curcuma longa is the source of the spice turmeric $[6,7,8,9]$.

Curcumin, the yellow color pigment of turmeric, is produced industrially from turmeric oleoresin[10].Various curcuminoids have been isolated from the rhizome of cucurma longa, attributing a wide array of biological activities such as antioxidant, anti imlammatory, wound healing activity $[6,11,8,9]$.

Natural products from some plants, fungi, bacteria and other organisms continue to be used in pharmaceutical preparations either as pure compounds or extracts [8].

The organolipitic properties of $C$. longa are odour, aromatic test warmly aromatic and bitter [9]. The active constituents of turmeric are the flavenoid, curcumin and volatile oils including turmerone,altantone and zingiberone. Other constituents include sugars, proteins and resins. The best active constituent is the dye curcumin, non toxic food which comprises 0.3 to $5.4 \%$ of raw turmeric [ 5,6]. The essential oil of C.longa inhibit the growth of variety of bacteria, parasites and pathogenic fungi, but neither was inactive against yeasts isolates. Curcumin has also been found to have moderate activity against pathogenic bacteria [1]. Ether and chloroform extracts of stem of C.longa were found to be fungestatic $[6,12,13]$ Total extracts of the dried powdered combination of fruits of M.charantia (cucurbitaceae ), E.officinalis (euphorbiaceae ) and rhizomes of C .longa (zingiberaceae ) showed better antibacterial activity compared to the individual plant ingredients alone[14]. The objective of this study was to determine the effect of various extracts of turmeric on pathogenic strains of gram- negative bacteria Salmonella typhimurium and Escherichia coli and grampositive bacteria Staphylococcus aureus and Bacillus cereus by zone of inhibition assay and their effect was compared to various standard antibiotics (gentamycin, ampicillin and erythromycin ) and to study the minimum inhibitory concentration of the most effected extract of rhizomes of curcuma longa on pathogenic bacteria.

\section{Materials and methods:}

Dry rhizomes of C.longa (turmeric) were purchased locally from local shops. The rhizomes $(50 \mathrm{gm})$ were ground finely and pestle by adding $(200 \mathrm{ml})$ water and subjected to steam distillation. The oily extract (fraction-A, 1.137gram) was collected and the residue in water was filtered. The filtrate was evaporated under vacuum to give water extract (fraction-D, 1.945 gram). The residue was air-dried and left overnight in chloroform $(100 \mathrm{ml})$, filtered and re-extracted twice with chloroform $(2 \mathrm{X} 50 \mathrm{ml})$. All chloroform extracts were combined and solvent was evaporated to give chloroform extract (fraction-B, $0.875 \mathrm{gram}$ ). The residue left after chloroform was extracted with methanol to give the methanol extract (fraction-C, 2.6gram), [2]. 
The gram-negative (Salmonella typhimurium, Escherichia coli) and the gram-positive bacteria (Staphylococcus aureus ,Bacillus cereus) were used as test organisms, they were obtained from College of Agricultural-food science and biotechnology and microbiological laboratory of the Central Organization for Standardization and Quality Control - Ministry of planning . Bacteria were grown on nutrient broth (Oxoid company) at $37^{\circ} \mathrm{c}$ for (24-48h) and then maintained on nutrient agar slants (Oxoid company) at $4 \dot{\circ}$. The extracts were dissolved in ethylene glycol, then filtered through membrane filter $(0.45 \mu \mathrm{m})$ sterilized and tested for antibacterial activity using disc diffusion method. Sterile 6.mm diameter filter paper discs were impregnated with $2000 \mu \mathrm{g}$ of the sterile test material and placed onto nutrient agar surface spread with $0.1 \mathrm{ml}$ of bacterial culture $\left(2.5 \times 10^{8}\right.$ cells $/ \mathrm{ml}$ using pour plate method). The plates were incubated at $37^{\circ} \mathrm{c}$ for $24-48 \mathrm{~h}$. The experiments were carried out in triplicate. The results were recorded by measuring the zone of inhibition around the discs. Control disc contains ethylene glycol only was used for comparison. Standard antibiotics (gentamycin, ampicillin, erythromycin) inhibiting bacterial protein synthesis were included in the reseach. The antibacterial spectra showing zone of inhibition in millimeters and as percentage calculated in accordance to gentamycin as positive control with $100 \%$ inhibition. The extracts A (essential oil) B (chloroform) C (methanol) and $\mathrm{D}$ (water) were tasted for anti -bacteria activity.

\section{Results and discussion:}

Results of Table(1) and (2) show that all the extracts were found inactive against gram positive Staphylococcus aureus and Bacillus cereus except extract-A(essential oil). Among gram- negative bacteria extract -A displayed moderate activity against Salmonella typhimurium and Escherichia coli while all other extracts were inactive. According to the results a bove minimum inhibitory concentration was studied only for essential oil (extract A) and results were compared with standards antibiotic.

Table (1): Zone of inhibition for various extracts of $C$.longa compared with some antibioticts

\begin{tabular}{|c|c|c|c|c|}
\hline \multirow{2}{*}{ Antibiotics } & \multicolumn{4}{|c|}{ Tested microorganisms } \\
\cline { 2 - 5 } & $\begin{array}{c}\text { Staphylococcus aureus } \\
\text { Zone of inhibition in mm }\end{array}$ & \multicolumn{2}{c|}{ Bacillus cereus } \\
& Meane of inhibition in mm \\
\hline & percentage & Mean & percentage \\
\hline Gentamycin 30 micg & $28.24 \pm 1.25$ & 100 & $20.28 \pm 0.92$ & 100 \\
Ampicillin 10 micg & $25.44 \pm 1.4$ & 87 & $8.42 \pm 0.42$ & 20 \\
Arthromycin 10 micg & $\mathbf{2 3 . 6 6 \pm 0 . 7 2}$ & 79 & $6.00 \pm 0.00$ & 0.00 \\
Fraction-A & $13.10 \pm 0.82$ & 32 & $14.42 \pm 0.82$ & 59 \\
Fraction-B & $6.00 \pm 0.00$ & 0 & $7.24 \pm 0.62$ & 9 \\
Fraction-C & $\mathbf{6 . 0 0} \pm \mathbf{0 . 0 0}$ & 0 & $6.74 \pm 0.48$ & 5 \\
Fraction-D & $10.24 \pm 0.62$ & 19 & $9028 \pm 0.78$ & 23 \\
Ethylene glycol & $6.00 \pm 0.00$ & 0 & $6.00 \pm 0.00$ & 0.00 \\
\hline
\end{tabular}

Mean value of diameter of inhibition zone with standard error as the diameter of paper disk used was $6 \mathrm{~mm}, 6 \mathrm{~mm}$ included in the table is indicative of no activity. Percentage was calculated after subtracting disc diameter (6) $\mathrm{mm}$ from all observations . 
Table (2): zone of inhibition for various extracts of $C$.longa compared with some antibioticts

\begin{tabular}{|c|c|c|c|c|}
\hline \multirow{2}{*}{ Antibiotics } & \multicolumn{4}{|c|}{ Tested microorganisms } \\
\cline { 2 - 5 } & $\begin{array}{c}\text { Salmonella typhimurium } \\
\text { Zone of inhibition in } \mathbf{m m}\end{array}$ & \multicolumn{1}{c|}{ Escherichia coli } \\
\cline { 2 - 5 } & Mean & percentage & Mean & Percentage \\
\hline Gentamycin 30 mcy & $32.14 \pm 0.87$ & 100 & $21.44 \pm 0.24$ & 100 \\
Ampicillin 10 mcy & $6.48 \pm 0.20$ & 2 & $13.26 \pm 0.64$ & 47 \\
Erthromycin 10 mcy & $6.00 \pm 0.00$ & 0 & $11.92 \pm 0.36$ & 38 \\
Fraction - A & $12.72 \pm 0.64$ & 29 & $8.22 \pm 0.22$ & 14 \\
Fraction - B & $6.00 \pm 0.00$ & 0 & $6.00 \pm 0.00$ & 0.00 \\
Fraction - C & $6.80 \pm 0.24$ & 4 & $6.60 \pm 0.24$ & 4 \\
Fraction - D & $7.24 \pm 0.00$ & 7 & $7.42 \pm 0.26$ & 9 \\
Ethylene Glycol & $6.00 \pm 0.00$ & 0 & 0.00 & 0.00 \\
\hline
\end{tabular}

It was observed that dilution altered the activity gradually in gram- positive bacteria to $78 \%$ and 59\% a gianst Staphylococcus aureus at 1/10 and 1/100 dilution respectively; however B.cereus did not show significant change at $90 \%$ at $1 / 10$ dilution, although activity decreased to $66 \%$ at $1 / 100$ dilution table (3) the gram - negative bacteria S. typhimurium and $E$. coil showed no activity below $400 \mu \mathrm{g} /$ disc concentration(1/100 dilution).

Table(3) : Minimum inhibitory concentration of fraction - A( essential oil ) on gram - positive bacteria with gentamycin as standard reference

\begin{tabular}{|c|c|c|c|c|}
\hline \multirow{2}{*}{ Antibiotics } & \multicolumn{4}{|c|}{ Tested microorganisms } \\
\cline { 2 - 5 } & $\begin{array}{c}\text { Staphylococcus aureus } \\
\text { Zone of inhibition in mm }\end{array}$ & $\begin{array}{c}\text { Bacillus cereus } \\
\text { Zone of inhibition in mm }\end{array}$ \\
\cline { 2 - 5 } & Mean & percentage & Mean & percentage \\
\hline Gentamycin 30 mcg & $29.24 \pm 0.66$ & 100 & $21.22 \pm 0.64$ & 100 \\
Fraction - A & $15.84 \pm 0.32$ & 42 & $15.28 \pm 0.42$ & 61 \\
1/10 of fraction A & $13.72 \pm 0.74$ & 33 & $14.44 \pm 0.32$ & 55 \\
1/100 of fraction A & $11.82 \pm 0.42$ & 25 & $11.62 \pm 0.32$ & 36 \\
Ethylene Glycol & $00 \pm 0.00$ & 0.00 & $6.00 \pm 0.00$ & 0.00 \\
\hline
\end{tabular}

The activity of the extract against E. coli was not affected at $1 / 10$ dilution (decrease $87 \%$ ) but it was at $1 / 100$ (decrease $62 \%$ ) table (4). 
Table (4): Minimum inhibitory concentration of fraction -A ( essential oil) on gram - negative bacteria with gentamycin as standard reference

\begin{tabular}{|c|c|c|c|c|}
\hline \multirow{2}{*}{ Antibiotics } & \multicolumn{4}{|c|}{ Tested microorganisms } \\
\cline { 2 - 5 } & $\begin{array}{c}\text { Salmonella typhimurium } \\
\text { Zone of inhibition in mm }\end{array}$ & $\begin{array}{c}\text { Escherichia coil } \\
\text { Zone of inhibition in } \mathbf{~ m m}\end{array}$ \\
\cline { 2 - 5 } & Mean & percentage & Mean & percentage \\
\hline Gentamycin 30 mcy & $22.45 \pm 0.26$ & 100 & $21.65 \pm 0.34$ & 100 \\
Fraction $-\mathbf{A}$ & $11.28 \pm 0.42$ & 33 & $\mathbf{8 . 4 5} \pm \mathbf{0 . 2 2}$ & 16 \\
1/10 dilution of fraction A & $\mathbf{8 . 4 3} \pm \mathbf{0 . 3 2}$ & 14 & $\mathbf{8 . 1 2} \pm \mathbf{0 . 2 2}$ & 14 \\
1/100 dilution of fraction A & $6.22 \pm \mathbf{0 . 1 2}$ & 1 & $7.54 \pm \mathbf{0 . 4 2}$ & 10 \\
Ethylene glycol & $\mathbf{6 . 0 0}$ & $\mathbf{0 . 0 0}$ & $\mathbf{6 . 0 0}$ & $\mathbf{0 . 0 0}$ \\
\hline
\end{tabular}

Essential oil extract is more effective against gram - positive compared to gram - negative B. cereus and S. aureus have shown 59 and $32 \%$ inhibition respectively compared to gram negative strains $S$. typhimurium and E. coli showing of inhibition 29 and $14 \%$ respectively. Extract - A (essential oil) shows comparable activity to standard antibiotics. It has shown highest inhibition in gram - positive B. cereus $(59 \%)$ and moderate activity in S. aureus (32\%) compared to erythromycin, ampicillin and gentamycin, while extract - A showed significant activity (29\%) against S. typhimurium compared to gintamycin table (2). The result is encouraging, as all other antibiotics were inactive against this bacteria. The present study suggest that essential oil extract from turmeric possesses significant antibacterial activity at very low concentration $(40 \mu \mathrm{g} / \mathrm{disc})$ on pathogenic gram - positive B. cereus and $S$. aureus. It has been suggested that the antibacterial effect of $C$. longa extracts is associated to the presence of hydroxyl and phenol groups in the molecule of turmeric beings essential for the inhibition of bacteria $[7,8,15]$.

\section{References:}

1. Federation of European Biochemical Societies (F.E.B.S) 1997.Inhibitory effect of curcumin on mammalian phospholipase.

2. Khattak .S,Saeed-ar.Rehman,Vllah Shan,Ahmad.W,Ahmad.M.2005.Biological effects of indigenous medicinal plants Cucurma longa and Alpinia galangal.pub med-indexed for MEDLINE15810156.76(2)254-7.

3. Martine AP, Salgueiro L, Goncalves MJ, Vila R, Canigueral S, massoni V ,Tomi F, sition and antimicrobial activity of prinicipe Pub Med - Indexed for MEDLINE , 11509990,67 (6), $580-4$.

4. Rambin , Rame sh, Mridula and Pratibha . 2002 . antibacterial activity of Cucurma longa rhizome extract on pathogenic bacteria . Current Science Vol . 83 .no .6.

5. Tonnesen HH, de vries H, Karlsen $\mathrm{J}$ and Beijersbergen 1987 . studies on curcumin using bacterial indicator systems $\mathrm{J}$ pharm sci ,76(5)371-3.

6. Alternative Medicine Review.2001.Cucurma longa.

7. Ibtehaj Mustafa Hakkem.(2006).Using tea and Christ thorm extract as antioxidants to improve the keeping quality of soft cheese and cream. M.S.thesis Baghdad University, College of Agriculture. 
8. Mem inst Oswaldo Cruz, Rio de Janero 2001 . Cucurma longa . Biological activities Vol . 96 (5) pp $723-728$.

9. Science Medicinal plant . 2006 Rhizomma Curcumae longa . PP. 1 -6.

10. Negi PS , Jayaprakasha GK Jan Antibacterial activity of Turmeric oil , a by product from curcumin manufactura . pub Med - indexed for MEDLINE ; 10552805 , 47 (10) $4297-300$.

11. Leal PF, Braga ME, Sato DN, Sato DN, Carvalbo Je meireles ma. 2003. functional properties of spice extract obtained via supercritical fluid extraction pub med. indexed for MEDLINE 12696930.

12. Kim KJ.Yu,HH cha JD.Sseo SJ.choi Ny.You 2005.Antibacterial activity of Curcuma longa against methicillin-resistant Staphylococcus aureus. Phytother Res.PP.599-604.

13. Misra SK, Sahu Kc .1977. Screening of some indigenous plants for antifungal activity against dermatophytes . Indian Journd of pharmacology. Vol .9. issus 4 pp 269 . 272.

14. Sankaranaray J, Jolly Cl. 1994. phytochemical antibacterial and pharmacological investigation on momordiea charantia linn . emblica officinalis gaertn and Eucurma longa linn Vol. 56 . iss. 1. PP. 6 - 13.

15. Nidha MS . (2004) Effect of some plant extracts as antimicrobial and food syctems . PH . D . thesis . Baghdad University . College of Agriculture. 